\title{
Activities of membarong on Dadak Merak mask dancers of Reog Ponorogo (Indonesia) and the effects on their teeth
}

\author{
Hayyumu Farina Nurhalizah \\ Department of Anthropology \\ Faculty of Social and Political Sciences, Universitas Airlangga, Indonesia \\ Address: Jalan Airlangga 4-6 Surabaya 60286, Indonesia \\ E-mail: hayyumufarinanrhlz@gmail.com
}

\begin{abstract}
Reog Ponorogo is an art that uses the Dadak Merak mask which is used by the dancer by biting on a wooden stick inside or commonly called cokotan. The Dadak Merak mask dancer is called pembarong, while the activity of playing the Dadak Merak mask is called membarong or mbarong. A pembarong may do a range of tricks, including kayang, gulungan, lifting the stacked Dadak Merak mask, and lifting the Dadak Merak mask while mounted on someone, all while the mask's weight exceeds $50 \mathrm{~kg}$ to $80 \mathrm{~kg}$. The researchers wanted to know if mbarong action on the Dadak Merak Reog Ponorogo dancer produces tooth wear and how many degrees of wear there are on the dancer's teeth. Cross-tabulation analysis is the data analysis technique employed in this paper. This study included 20 pembarong respondents, ranging in age from 15 to 50 years old. The conclusions of this study show that mbarong exercise produced tooth wear in the dancers, with the most severe wear occurring in the first and second molars. The fulcrum of the Dadak Merak mask load on those teeth causes wear in the first and second molar teeth.
\end{abstract}

Keywords: tooth wear; degree of wear; pembarong; Dadak Merak mask

Article History

Received: October 22, $2021 \quad$ Accepted: October 28, 2021

Cite this as: Nurhalizah HF (2021) Activities of membarong on Dadak Merak mask dancers of Reog Ponorogo (Indonesia) and the effects on their teeth. Indonesian Journal of Social Sciences 13 (2):101-109. DOI 10.20473/ijss.v13i2.30872.

\section{Introduction}

Reog Ponorogo art is a form of culture originating from the local community in dances accompanied by music. The history of Reog Ponorogo has several versions that have not been scientifically proven because its history is only myth or legend (Kurnianto 2013). Reog Ponorogo has four historical versions, namely the Bantar Angin version, the Wengker version, the Surukubeng version, and the Kediri version (Turhumawati 2008).

Teeth are tissues in the body that have functions for chewing, speaking, and beautifying the face (Tim Dian Rakyat \& Suryawati 2010). Teeth consist of several tissue structures that compose them. The tissues that make up the teeth include dentin, cementum, alveolar bone, pulp chamber, appical foramen, and gingival tissue (Artaria 2009). Teeth have terms to make them easier to pronounce, including: 1.) $\mathrm{I}=$ Incisor, 2.) $\mathrm{C}=$ Canine, 3.) $\mathrm{P}=$ Premolar, 4.) $\mathrm{M}=$ Molar.

The teeth are divided into four quadrants: lower left, lower right, upper left, and upper right, as shown in Figure 1. The mention of the teeth in this study is based on the quadrant and the term teeth above. The mention of the parts of the teeth is arranged by mentioning the parts of the teeth $\mathrm{I} / \mathrm{C} / \mathrm{P} / \mathrm{M}$ plus the number $1 / 2 / 3$, then marked with a dot (.) followed by the mention of the quadrant part. For example, the mention of the third molar on the lower left, it can be written as M3.LL (lower left third molar). 
Tooth wear is used to describe the loss of hard tooth tissue caused by non-carious decay (Smith \& Knight 1984). Tooth wear is a multifactorial process because tooth wear is caused by two or more types of wear (Pickles 2006). In tooth wear cases, there may be one type of wear that dominates but is supported by other types of wear. Oltamari-Navarro et al. (2010) also support the opinion of Pickles (2006) that the causes of tooth wear cannot be separated from each other because these conditions are often combined.

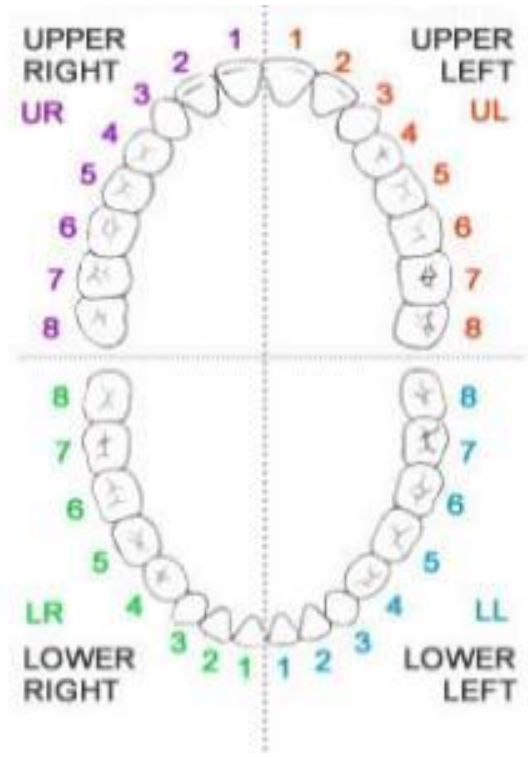

Figure 1.

Quadrants of the teeth

Source: www.dentalfearcentral.org/

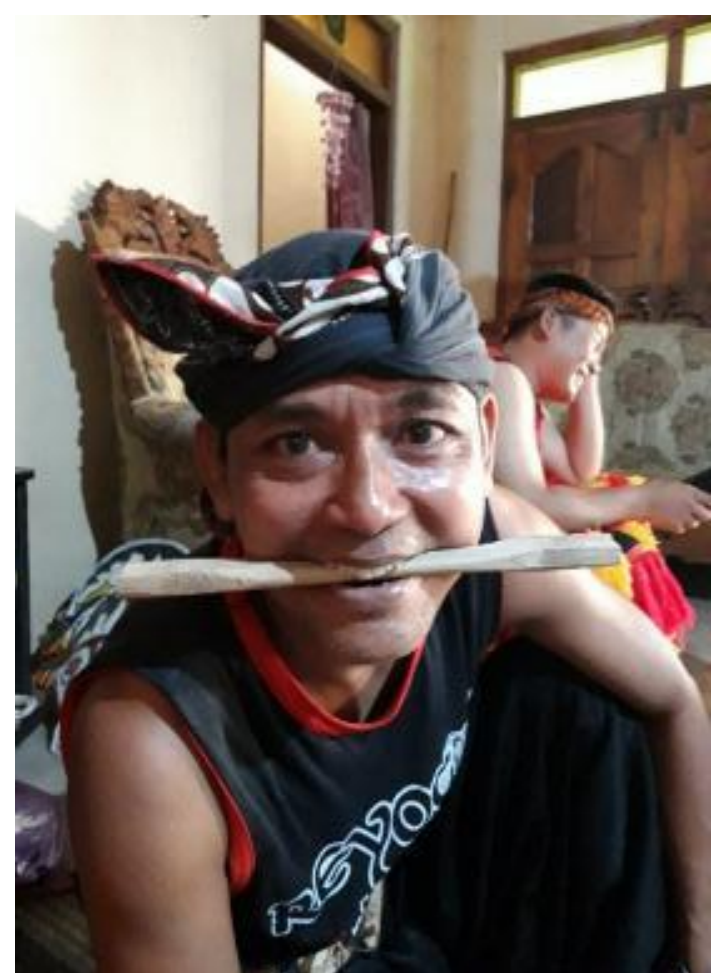

Figure 2.

Cokotan used by the dancer (pembarong) to help him holding the heavy mask by his teeth

Pickles divided tooth wear into two types: tooth wear caused by chemicals and physical contact (Pickles 2006). Erosion is a type of wear induced by chemicals, whereas abrasion and attrition are types of wear caused by physical contact. He went on to say that tooth wear induced by physical contact and chemicals that destroy the hard tissues of the teeth might appear in different forms and combinations in different people. The phrase "tooth wear" is more convenient to use because it encompasses all of the different reasons of hard tooth tissue loss.

Imfeld (1996) is the source for the following explanation of erosion and abrasion. Erosion is derived from the Latin words eredere, erosion, and erosum, which means to corrode and eat away. Erosion is a condition in which a surface is continuously damaged. Erosion is caused by electrolytic or chemical reactions. Tooth erosion is a term used to describe a condition in which hard tooth tissue is lost over time due to acids and/or chelation (chemicals used to soften tooth structure) without the involvement of germs. Foods (such as fruit) and some drinks contain acid, as do substances originating from the body that reflux into the oral cavity (such as stomach acid).

Abrasion comes from the Latin verb abradere, abrasion, abrasum, which means to scrape. Abrasion describes a condition of wear and tear on an object or coating due to mechanical processes (e.g., grinding, scraping, or rubbing. Abrasion on teeth refers to wear and tear on the hard tissues of the teeth caused by abnormal mechanical processes such as repeated usage of foreign items or substances 
injected into the mouth and coming into direct contact with the teeth. Abrasion is influenced by both individual and material elements - individual factors such as how to brush teeth, brushing time, brushing frequency, and any others. The flexibility of the toothbrush, the shape of the toothbrush, and the toothpaste content are all explained.

Pickles (2006) explained that the most common causes of abrasion are eating abrasive foods, using an abrasive and excessive toothbrush and toothpaste products, and work (e.g., cutting floss, holding screws, or nails with your teeth). He also explained that tooth enamel, the most rigid material in the human body, would not survive direct mechanical contact. The mechanical process can be in the form of chewing, biting, and brushing teeth continuously and followed by very high forces, resulting in changes in the shape (wear) of the teeth. That means that tooth abrasion will only occur if the tooth has direct contact with an object or material that is harder than enamel or dentin.

Attrition defines the loss of hard tooth tissue that occurs due to physical contact of the teeth with other objects without the influence of chemical substances (Pickles 2006). The majority of attrition occurred in the opposing teeth at the incisal edges of the anterior teeth and the occlusal surfaces of the posterior teeth. Further attrition can lead to erosion of the cusps and a flat crown surface (Bartlett \& Shah 2006). Attrition is reinforced by the presence of an abrasive diet (Gahr 1987).

My interest on Reog Ponorogo culture prompted this study, because the splendor of its art, Reog Ponorogo has another intriguing aspect. It is about how a dancer of the Dadak Merak mask, also known as pembarong, who can raise the mask, which weights between 50 and 80 kilograms, with his teeth. In Reog Ponorogo, a Barong mask or Dadak Merak mask is characterized as a Harimau Gembong, the forest's lord, with a peacock - a teenager wearing peacock costume - on top of the bigheavy-mask. The Dadak Merak mask weighs approximately $50 \mathrm{Kg}$ to $80 \mathrm{Kg}$ (Suryanti et al. 2017).

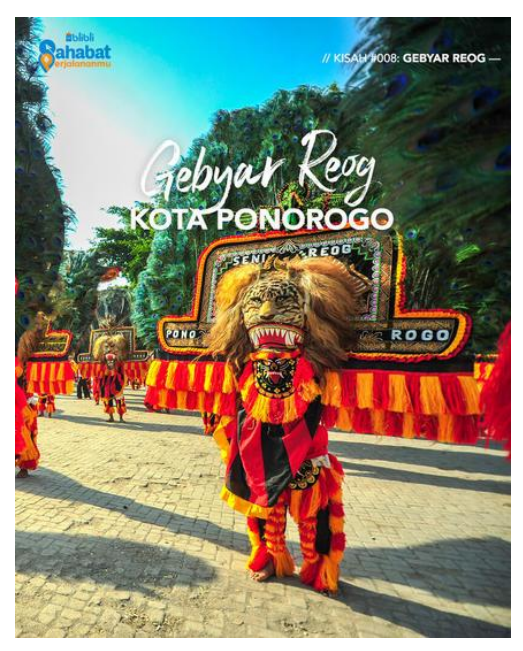

Figure 3.

Pembarong holding the heavy mask by his teeth

Source: https://www.kaskus.co.id /thread

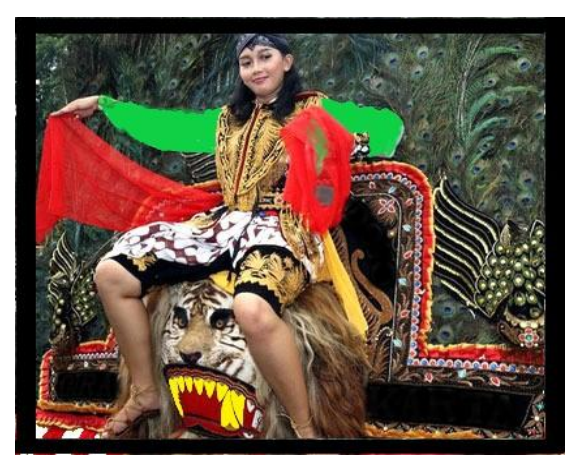

Figure 4.

A teenager is sitting on top of the heavy mask, while pembarong is holding the mask by his teeth Source: https://mbludus.com/

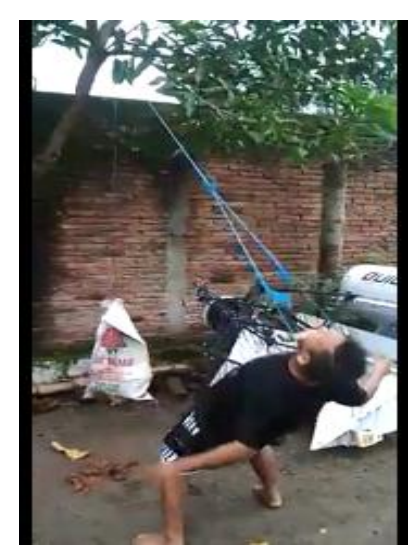

Figure 5.

The pembarong carries out the pulley exercise method Source: www.youtube.com

The pembarong wear the Dadak Merak mask by being carried over their heads, biting and holding them (Figure 2). The mask dancer Dadak Merak moves his mask according to the desired movement. This mask has a position that is not attached to the dancer's face, but there is a piece of wood that is bitten or called cokotan to support the load, and there is a hole in the mouth of the mask that the 
dancer uses to see the conditions outside (Hidayanto 2017). That is considered very interesting for the author in terms of the condition of the teeth of the Dadak Merak mask dancer who can lift the weight of the Dadak Merak mask, which reaches $50 \mathrm{Kg}-80 \mathrm{Kg}$ (Figure 3), and holding the mask using his teeth while someone is sitting on top of the mask (Figure 4).

A pembarong would need the strength of his teeth, jaw, and neck bones to lift the Dadak Merak mask, which weighs 50 to $80 \mathrm{~kg}$. The strength of a pembarong is not immediately obtained. They have to practice before lifting Dadak Merak $50 \mathrm{~kg}$ to $80 \mathrm{~kg}$ weight (Figure 5).

The dancers with special training achieve this ability to build strength. Some people also believe that this power comes from magical powers, so a special ritual is needed to summon the "help" (Oktyawan 2014). There are various rituals that the performers have to perform either before or after their performance. An example is the obligation to fast and make offerings. Some Reog art groups also drink herbal medicine, which they believe is a stamina enhancer when performing.

Every human behavior certainly has an effect, both in the long and short term. This includes the actions of the pembarong Reog Ponorogo. Giving excessive load on the teeth, of course, will result in permanent structural damage. Permanent structural damage occurs in the hard tissues of the teeth or commonly referred to as tooth decay. This phenomenon is formulated in the formulation of the problem as follows; 1) does the activity of membarong (playing Barong or Dadak Merak mask) on the Dadak Merak mask Reog Ponorogo dancer cause wear and tear on the teeth? 2) What is the degree of tooth wear for the dancers of Dadak Merak mask Reog Ponorogo?

\section{Methods}

The location of the research was conducted on several Reog art groups in Ponorogo Regency. The arts groups were Reog Ponorogo art group in Kemuning Village, Joyo Loreng art group, Ronosetanan Village, and the art group in Golan village, Ponorogo Regency.

The research subjects used are Dadak Merak dancers with a minimum playing intensity of two years. The selection of research subjects with the duration of playing the Dadak Merak mask for at least two years aimed to see tooth wear. Tooth wear can be more visible if it is done with a long enough playing time so that contact with the teeth occurs for a long time.

The number of informants used in this study was 20 Dadak Merak dancers. The age of the individuals in this study ranged from 15 to 50 years old, depending on when permanent teeth were present. The informants selected are determined by the data available in the field. As a result, the age range of the informants was quite wide.

The research was descriptive quantitative in nature. According to Yusuf (2014), quantitative descriptive research is a structured attempt to find a solution to a problem or an attempt to acquire more complete and extensive data on an event utilizing quantitative research steps. The goal of this research is to create a description or image of the events that are being investigated and analyzed utilizing statistics and narrative.

According to Margono (1997), the act of observing and recording activity on the item under investigation is known as observation. In order to understand the study's conditions, observations were made, and the researcher will determine whether or not to continue the study based on the findings.

Researchers' observations are non-participant observations, with the researcher acting as an observer. The observations were conducted in two ways: directly and indirectly. Indirectly, by relying on information gleaned from the object's documentation. Meanwhile, the researcher conducted direct observation by approaching one of the research objects directly. 
Interviews were conducted by asking several questions related to the activities of the pembarong. Interviews were conducted to find out in-depth their activities and lifestyles related to their dentition. This was done to discover whether there were any additional factors that could alter the status of the dentition.

The Tooth Wear Index, developed by Smith \& Knight (1984) (Table 1), was used to take measurements. This tooth wear index is a modified version of the World Health Organization's (WHO) tooth wear index, but it still meets the standards. This improved version offers the advantage of a simple and accurate measurement approach. There was a code for teeth restored due to wear (code 4) and a code for teeth that could not be assessed on that measuring index (code 9). That came in handy while dealing with a variety of data results on the field.

This study used documentation in the form of photos on the teeth of Reog dancers. The documentation was carried out to see more clearly and perpetuate the identity of each informant. The documentations are included within the last pages of this report.

The data analysis technique used in this research is cross-tabulation analysis or Crosstabs. The crosstabulation analysis served to see the percentage and frequency of two or more variables simultaneously by crossing these variables so that the relationship between these variables can be explained descriptively (Santoso \& Tjiptono 2001).

Table 1.

The criteria used in the measurement of tooth wear are based on the modified tooth wear index

\begin{tabular}{|c|c|c|c|}
\hline \multicolumn{2}{|c|}{ Degree } & \multirow[b]{2}{*}{ Criteria } & \multirow[b]{2}{*}{ Description } \\
\hline $\begin{array}{l}\text { Primary } \\
\text { teeth }\end{array}$ & $\begin{array}{l}\text { Permanent } \\
\text { teeth }\end{array}$ & & \\
\hline$a$ & 0 & Normal e no evidence of wear & No loss of surface features \\
\hline$b$ & 1 & $\begin{array}{c}\text { Incipient e tooth wear into } \\
\text { enamel }\end{array}$ & $\begin{array}{c}\text { Loss of enamel giving a smooth } \\
\text { glazed shiny appearance, dentine is } \\
\text { not involved }\end{array}$ \\
\hline c & 2 & $\begin{array}{l}\text { Moderate e tooth wear into } \\
\text { dentine }\end{array}$ & $\begin{array}{l}\text { Extensive loss of enamel with dentine } \\
\text { involvement. Exposure of dentine }\end{array}$ \\
\hline$d$ & 3 & Severe e tooth wear into pulp & $\begin{array}{c}\text { Extensive loss of enamel and dentine } \\
\text { with secondary dentine or pulp } \\
\text { exposure }\end{array}$ \\
\hline e & 4 & $\begin{array}{c}\text { Restored e tooth wear leading to } \\
\text { restoration. }\end{array}$ & $\begin{array}{l}\text { The tooth received restorative } \\
\text { treatment due to tooth wear }\end{array}$ \\
\hline e & 9 & Could not be assessed & $\begin{array}{l}\text { Extensive caries, large restoration, } \\
\text { fractured tooth, missing tooth, } \\
\text { orthodontic brackets }\end{array}$ \\
\hline
\end{tabular}

Sources: Smith \& Knight (1984)

\section{Results and Discussion}

On average, respondents who engage in membarong activities can perform staging twice a week. Performances are also affected by the Javanese calendar month; when August, September, and October arrive, there will be a surge in requests for performances. Festivals, Independence Day, and 
the commemoration of the month of Assyura or Suro are all held during this month. Performances can be performed by twice as many people in that month, even on a daily basis.

In the Reog Obyog type of performance, the Barong can perform for 15 minutes to 30 minutes, and in the Reog Festival style of performance, the Barong can perform for 5 minutes or more. At the age of 15 to 17 , the artisans begin practicing with the Dadak Merak mask.

The respondents were unable to play the $60 \mathrm{~kg}$ Dadak Merak mask right away, but they began with practicing. The practice activities carried out by the pembarongs were weight training using pulleys. The weight of the load ranges from $5 \mathrm{~kg}$ to $50 \mathrm{~kg}$. Baban exercises are carried out in stages, from light to heavy loads. There is some pain in the teeth and jaw as a result of this workout, but when they get acclimated to it, there is no pain. What respondents did to treat the pain was to compress it using ice. Respondents also consume beverages such as Jати Parem, Jamu Pegel Linu, honey, eggs, and paitan which serve as stamina enhancers. One respondent admitted that some of the performers have a habit of consuming alcoholic beverages made of red wine, which increases their self-confidence when performing. Smoking was a habit of the respondents. All of the respondents admitted to smoking cigarettes on a regular basis.

Based on the scoring, the respondent's teeth are showing signs of wear and tear. The wear patterns on the lower and upper incisor teeth are different but similar. The lowest incisors had the highest wear rate, with a score of 0 and a proportion of more than 55\% of the total responses. This is also seen in the upper incisors, where teeth with a score of 0 account for more than $60 \%$ of the total.

Wear on the lower incisors with a score of 1 is greater than on the upper incisors. That is demonstrated by the fact that the proportion of scoring in the lower incisors is 30 percent to 35 percent, whereas the percentage in the upper incisors is only 20 percent to 30 percent. Wear and tear, with a score of 2, affects just the lower incisors, with a percentage of 5 percent to $10 \%$, or 1-2 responses. Scoring with a value of 4 is similarly only found in the upper incisive, where it affects only one individual, because his teeth were destroyed and he could not function effectively, the respondent underwent dental restoration.

The wear score with a value of 9 is mainly found in the upper incisors, i.e., two people experience it. In the lower incisors, only one person aged 39-44 years gets a score of 9 .

The score of 0 is 55 percent to 60 percent higher than the other scoring values, according to the results. In the 39-44 year age group, wear and tear with a score of 1 has a percentage of 35 percent, while a score of 9 has a percentage of 5 percent to $10 \%$. Only one person (or $5 \%$ of respondents) received a score of 4 because the respondent undertakes dental repair due to serious tooth decay.

Premolars with a score of 0 have a percentage of $40 \%$, while those with a score of 1 have a percentage of 45 percent to 50\%. Only one respondent aged 39-44 years old with a proportion of 5\% has wear on a score of 2 . On a scale of one to ten, a score of nine has a percentage value of $5 \%$ to $10 \%$. P2.LL, P1.LR, and P2.LR have a percentage score of 9, which is greater than $10 \%$, whereas the other teeth have a score of $5 \%$.

The majority of wear on the first molars is detected with a score of 1 , which indicates a wear percentage of $50 \%$ to $60 \%$. Wear and tear with a score of 9 is experienced by $1-2$ respondents ( 5 percent - 10 percent), with one respondent or a percentage of 5 percent at the age of 39 - 44 years, and two respondents or a percentage of 10 percent at the age of $15-20$ years and $21-26$ years. Wear on a score of 0 has a percentage range of $15 \%$ to $20 \%$. The average wear score for the first two and three molars is $5 \%$ or one respondent, however the M1.LR score with a value of 3 has a percentage of $15 \%$ of the respondents.

With 60 percent to 65 percent of responses, the second molar is dominated by a score of one. Except for M2.LL, which has a percentage of $25 \%$ of responses, a score of 0 has a proportion of $20 \%$. In this 
dental segment, the percentage score of 2 is only $5 \%$, or one individual. The lower molar's wear score of 3 is higher in percentage than the upper. The lower molar has $10 \%$ to $15 \%$ of the total, while the upper molar has just 5\%. A score of 9 was also discovered in the upper molar, which was not observed in the lower molar. In the 39-44 year old age group, the percentage of lower molars with a score of 9 is $5 \%$.

Some respondents' third molars were missing, resulting in a significant percentage of wear and tear with a score of 0 , which was between 50 and 60 percent. This is inversely related to the wear scores on the first and second molars, where the wear score is a low 0 . There was wear and tear in the third molar in some respondents who appeared, with a score of 1 ranging from $15 \%$ to $35 \%$, and a score of 2 ranging from $5 \%$ to $10 \%$, which only appeared at the age of 39 to 44 years. Teeth with wear scores of 3 and 9 were identified at the same age, i.e., 39-44 years, with each having a wear percentage of $5 \%$ of the respondents.

The teeth of the first and second molars have a significant wear rate, according to the results of the statistical analysis of the teeth of the 20 respondents. This is demonstrated by the percentage score of 0 in M1, which is only $15 \%$ to $20 \%$, and in M2, which is only $20 \%$ to $25 \%$, while the remaining percentages have scores of $1,2,3,4$, and 9 in each section of the tooth.

Wear on M3 teeth has a lower percentage than wear on M1 and M2. That is seen by the percentage score of 0 being as high as 50\%-60\%. According to the findings, the high percentage score of 0 was due to the fact that the M3 teeth did not show in certain respondents, and the Dadak Merak mask dance movements did not use M3 teeth. Depending on the width of the mouth, M3 teeth are used or not as a support for the Dadak Merak mask load. If the pembarong has a wide mouth and an M3, then the M3 will be at risk of wear and tear and vice versa.

The premolars are another region of the tooth that gets a lot of wear and tear. The results of the study of the respondents' teeth show that only $40 \%$ of those who suffered wear with a score of 0 had wear, whereas $60 \%$ had wear with a score of 1 to 9 .

The results showed that the most significant wear was on the premolars and molars. The usage of the teeth to support a large weight in the dance movement of the Dadak Merak mask causes the teeth to wear out quickly. Mayhal (in Taylor 1986) described tooth wear in Eskimo women in a similar way. The wear and tear in Eskimo women are primarily found in the lower incisors and premolars because these teeth are often used to smooth animal hides as the raw material for their clothes. Chewing and biting, pinching, and piercing are the methods they use to smooth the hides, which results in tooth wear.

Based on the observation conducted, several respondents experienced caries. Caries is linked to the amount of cigarettes that the respondents smoke on a regular basis. Zitterbart, Matranga, and Christen explained that caries would be more common in smokers than nonsmokers (Zitterbart et al. 1990). Smoking causes decreased salivary excretion so that the level of protection against teeth is reduced (Ravald et al. 1993). Tobacco containing nicotine will cause many pathogens that cause dental caries (Streptococcus mutans) to adhere to the tooth surface, increasing and exacerbating caries' risk (Liu et al. 2018).

\section{Conclusion}

Membarong activities cause wear and tear on the dancers' teeth. This activity illustrates that the movements carried out by the pembarong are extreme. The movements carried out by the dancers have a long duration, coupled with the weight of Dadak Merak mask, resulting in tooth wear on the dancers' teeth. 
The Dadak Merak dancers' tooth wear ranges from 0 to 9 , with 0 being the least worn. When compared to other teeth, the teeth that are frequently used as footing will have a lot of wear. The wear and tear on the respondent's teeth is also influenced by his age. The higher the wear rate, the older the respondent. That has something to do with the length of time he has been doing membarong.

Based on the study results, it can be seen that the wear on the teeth of the Dadak Merak dancers has a pattern. The most common wear on the first and second molars with the percentage of wear is $80 \%$ $85 \%$, and $75 \%-80 \%$, respectively. The wear on the incisor and canine teeth has the lowest wear rate. That is indicated by the percentage score of 0 in both teeth ranging from 55\% - 60\%.

\section{References}

3 Hal Menarik Tentang Kota Ponorogo Yang Wajib Agan Tau! (2020) [Diakses 3 Oktober 2021] https://www.kaskus.co.id/thread/5f277ced68cc950f045ab7f0/3-hal-menarik-tentang-kota-ponoro go-yang-wajib-agan-tau/.

Artaria MD (2009) Antropologi Dental. Yogyakarta: Graha Ilmu.

Bartlett DW \& Shah P (2006) A critical review of non-carious cervical (wear) lesions and the role of abfraction, erosion, and abrasion. J. Dent. Res. 85 (4):306-312.

Gahr KHZ (1987) Microstructure and wear of materials. Elsevier.

Hidayanto AF (2017) Topeng reog ponorogo dalam tinjauan seni tradisi. J. Eksis 8 (1):2001-2181.

Imfeld T (1996) Dental Erosion: Definition, Classification and Links. Eur. J. Oral Sci. 104:151-155.

Kurnianto R (2013) Sejarah dan Dinamika Seni Reyog Ponorogo. In: Dialog Budaya Program Summer Course, 5 Oktober 2013, Ponorogo.

Liu S, Wu T, Zhou X, Zhang B, Huo S, Yang Y, Zhang K, Cheng L, Xu X, \& Li M (2018) Nicotine is a risk factor for dental caries: An in vivo study. Journal of Dental Sciences 13 (1):30-36.

Margono S (1997) Margono, Metode Penelitian Pendidikan. Jakarta: Rineka Cipta.

Oktyawan DS (2014) Makna Simbolik Upacara Ritual dalam Kesenian Reog Ponorogo di Desa Kauman Kecamatan Kauman Kabupaten Ponorogo. Skripsi, Universitas Negeri Yogyakarta, Yogyakarta.

Oltamari-Navarro PVP, Janson G, de Oliveira RBS, Quaglio CL, Henriques JFC, Sales-Peres SHdC, \& Mc Namara Jr JA (2010) Tooth-wear patterns in adolescents with normal occlusion and class II division 2 malocclusion. Am. J. Orthod. Dentofac. Orthop. 137 (6):730. DOI 10.1016/j.ajodo.20 10.01.020.

Pickles M (2006) Tooth Wear. In: Duckworth RM (ed), The Teeth and Their Environment. Monogr Oral Sci. Basel, Karger, 19:86-104. DOI 10.1159/000090587.

Ravald N, Birkhed D, \& Hamp SE (1993) Root caries susceptibility in periodontally treated patient: result after 12 years. J. Clin Periodontol 20 (2):124-9.

Reog Ponorogo (2019) [Diakses 3 Oktober 2021]. https://mbludus.com/reog-ponorogo/.

Santoso S \& Tjiptono F (2001) Riset Pemasaran Konsep dan Aplikasi dengan SPSS. Jakarta: Elex Media Komputindo.

Smith B \& Knight J (1984) An index for measuring the wear of teeth. Brithish Dent. J. 156 (12):435438.

Suryanti N, Darmawati, \& Desfiarni (2017) Bentuk penyajian kesenian reog ponorogo di Jotong Koto Agung Nagarai Sangai Duo Kecamatan Sitiung Kabupaten Dharmasraya. E-Jurnal Sendratasik 6 (1 Seri C):1-9.

Taylor RMS (1986) Sealskin softening by teeth - A Maori Case?. J. Polyn. Soc. 95 (3):357-369.

Tim Dian Rakyat \& Suryawati NP (2010) 100 Pertanyaan Penting Perawatan Gigi Anak. Jakarta: Dian Rakyat.

Tooth Number (2020) [Diakses 4 May 2020]. https://www.dentalfearcentral.org/faq/tooth-numberingsystems/. 
Indonesian Journal of Social Sciences Volume 13 No. 02, July-December 2021, page 101-109

Turhumawati (2008) Kesenian Reog Sebagai Daya Tarik Wisata Budaya di Kabupaten Ponorogo. Laporan Tugas Akhir, Universitas Sebelas Maret.

Tutorial belajar reog masa kini (2017) [Diakses 7 July 2020]. https://www.youtube.com/watch?v=M2 EzYsQRZew

Yusuf AM (2014) Metode Penelitian: Kuantitatif, Kualitatif, dan Penelitian Gabungan, Pertama. Jakarta: Kencana

Zitterbart PA, Matranga LF, Christen AG, Park KK, \& Potter RH (1990) Association between cigarrete smoking and the prevalence of dental caries in adult males. Gen Dent 38 (6):426-31. 